\title{
PENGARUH TERAPI MUROTTAL QUR'AN TERHADAP INTENSITAS NYERI PERSALINAN KALA I FASE AKTIF DI BIDAN PRAKTIK MANDIRI (BPM) ERNITA KOTA PEKANBARU TAHUN 2017
}

\author{
Fatiyani Alyensi' ${ }^{1}$, Hafsah Arifin ${ }^{2)}$ \\ E-mail address : fatiyaniyensi@yahoo.co.id
}

\begin{abstract}
As a physiological state in labor, pain causes discomfort due to stimulation at certain nerve endings. One of ways considered to eliviate the pain is by listening to Qur'an recital (murottal). This therapy stimulates delta waves which make the listener more relax, peaceful, and comfortable so that hypopfise and hypothalamus produce $\beta$ endorphin as natural analgesic This research aimed to determine the influence of Qur'an recital therapy to the intensity of labor pain during the first stage in the active phase. This was a quasi experimental research with a pre-test post-test group design conducted from February to July 2017 at BPM (privately practising midwife) Ernita of Pekanbaru. The subjects were 20 mothers with normal delivery taken with purposive sampling technique. The data were collected by pain measurement method before and after the Qur'an recital treatment 30 minutes with the combined pain scale of Verbal Description Scale (VDS), Comparative Pain Scale and Wong Baker Pain Rating Scale. Data processing is computerized with dependent t-test $(\alpha=0.05)$. The results showed that the mean intensity of labor pain before the treatment was 6.75 and after the treatment was 4.80 . The data analysis showed that there was a difference in the intensity of labor pain in the active phase before and after being given the treatment $(p=0,000)$. It is recommended to BPM Ernita to disseminate the Qur'an recital therapy as one of the non-pharmacologic pain reduction methods in childbirth so that it can be a procedure as an effective method in reducing labor pain.
\end{abstract}

Keywords : Labor Pain; Murottal Qur'an

1) Poltekkes Kemenkes Riau

\section{Pendahuluan}

Salah satu kebutuhan seorang ibu dalam proses persalinan adalah mendapatkan bantuan untuk meringankan rasa nyeri. Nyeri merupakan keadaan fisiologis dalam persalinan yang menimbulkan rasa tidak nyaman akibat rangsangan pada ujung-ujung saraf tertentu. Selama persalinan, nyeri disebabkan oleh kontraksi rahim, dilatasi serviks dan distensi perineum. Rasa nyeri saat persalinan bersifat unik dan berbeda pada setiap individu, hal ini dikarenakan rasa nyeri tersebut dipengaruhi oleh rasa takut atau kecemasan terhadap persalinan, 
kelelahan selama proses persalinan, sosial budaya, dan pengalaman melahirkan yang terdahulu (Henderson C dan Jones K, 2005; Rohani dkk, 2011).

Nyeri persalinan yang berlebihan dan terlalu lama akan menimbulkan kecemasan dan tekanan psikologis, sehingga dapat mempengaruhi keadaan fisik ibu bersalin, seperti peningkatan tekanan darah, frekuensi nafas dan denyut jantung. Apabila hal ini terus terjadi, maka nyeri yang hebat selama persalinan dapat menimbulkan kelelahan pada ibu sehingga berisiko terjadinya partus lama yang dapat membahayakan ibu dan janin. Kebanyakan ibu mengalami nyeri persalinan pada tingkat yang sedang sampai berat. Ranta. P dkk (1995) mengemukakan bahwa, $89 \%$ ibu bersalin primipara dan $84 \%$ ibu bersalin multipara menggambarkan nyeri persalinan sebagai nyeri yang sangat berat dan tidak tertahankan. Hal ini menunjukkan bahwa, ibu bersalin primipara dan multipara sama-sama merasakan nyeri yang hebat selama persalinan (Potter PA dan Perry AG, 2005; Saifuddin dkk, 2010; Ranta, P. dkk, 1995).

Banyak metode yang dapat dilakukan untuk mengurangi nyeri persalinan, baik secara farmakologi maupun non-farmakologi. Metode nonfarmakologi mempunyai keuntungan dalam segi pelaksanaannya, yaitu lebih mudah diterapkan dan minim efek samping terutama untuk janin, karena janin sangat rentan terhadap ancaman substansi kimia yang berasal dari obatobatan. Metode non-farmakologi yang dapat diterapkan dalam mengurangi nyeri persalinan adalah teknik relaksasi dengan pengaturan nafas, psikoprofilaksis, hipnoterapi, massase, hidroterapi, akupuntur, stimulasi saraf elektrik transkutaneus (TENS), pergerakan fisik yang berpola/pengaturan posisi, pendampingan persalinan, aromaterapi, shiatsu, distraksi dan lain-lain (Henderson. C dan Jones. K., 2005; Reeder. SJ dkk, 2011; Medfotrh. J, dkk, 2011).

satu metode distraksi yang menggunakan suara sebagai stimulus, seperti musik, white noise, musik instrumental dan suara lain yang membantu menurunkan persepsi seseorang terhadap nyeri. Terapi ini dapat menstimulasi gelombang delta yang menyebabkan pendengar dalam keadaan tenang, tentram dan nyaman sehingga hypopfise dan hypothalamus mengeluarkan $\beta$-Endorphin sebagai analgesik alamiah

Stimulus

sensori menyenangkan yang berasal dari suara akan melepaskan endorphin sehingga dapat memberikan ketenangan. Banyak penelitian yang menyatakan bahwa memberikan terapi berupa suara dapat meningkatkan ambang batas nyeri seseorang, membangkitkan mood dan membantu mengatur pernafasan (Simkin. B dan Bolding. A., 2004).

Terapi audioanalgesia dapat meringankan rasa sakit, karena dapat mengalihkan rangsangan nyeri kepada suara yang didengarkan. Murottal Qur'an adalah salah satu jenis audioanalgesia yang dapat diberikan kepada ibu bersalin. Murottal adalah seni membaca Al-Qur'an yang memfokuskan pada kebenaran bacaan dan lagu Al-Qur'an. Mendengarkan lantunan ayat suci Al-Qur'an akan 
terasa lebih indah dan menyentuh apabila dilagukan dengan irama yang indah, sehingga dengan memberikan terapi murottal Qur'an pada ibu bersalin, dapat membantu ibu dalam mengurangi nyeri persalinan (Reeder. SJ dkk, 2011; Simkin. B dan Bolding. A., 2004; Anonim, 2014).

Bidan Praktik Mandiri (BPM) Ernita merupakan salah satu klinik bidan dengan rata-rata jumlah persalinan terbanyak setiap bulannya, yaitu sebanyak 25-30 persalinan. Metode pengurangan nyeri persalinan yang diterapkan di BPM Ernita adalah teknik relaksasi, massase punggung, dan belum pernah diterapkan penggunaan terapi murottal Qur'an .

Penelitian ini dilakukan untuk mengetahui pengaruh terapi murottal Qur'an terhadap intensitas nyeri persalinan kala I fase aktif di BPM Ernita Kota Pekanbaru tahun 2017.

\section{Metode Penelitian}

Jenis penelitian ini adalah quasi eksperimen dengan desain pre-test post-test group, yaitu membandingkan intensitas nyeri persalinan sebelum dan sesudah diberikan perlakuan. Pada penelitian ini dilakukan pre-test dengan mengukur keadaan awal intensitas nyeri persalinan, selanjutnya diberikan perlakuan berupa terapi murottal Qur'an selama 30 menit dan dilakukan post-test berupa pengukuran kembali intensitas nyeri pada kelompok tersebut.

Populasi dalam penelitian ini adalah seluruh ibu bersalin normal di BPM Ernita selama periode penelitian. Pengambilan sampel dilakukan dengan teknik purposive sampling dengan jumlah sampel sebanyak 20 orang ibu bersalin kala I fase aktif (pembukaan serviks 4-8 cm). Kriteria inklusi dalam penelitian ini adalah ibu bersalin yang bersedia menjadi responden dengan menandatangani informed concent, beragama islam, usia kehamilan aterm, serta tidak menggunakan obat pereda nyeri. Kriteria ekslusi yang ditetapkan peneliti adalah ibu bersalin yang mengalami komplikasi selama persalinan kala I fase aktif dan dilakukan induksi persalinan.

Pemantauan kondisi ibu dilakukan dengan menggunakan lembar partograf untuk menilai kemajuan persalinan, bila sudah masuk pada kala I fase aktif maka dilakukan pengukuran intensitas nyeri (pre test), lalu diberikan terapi murottal Qur'an surat Arrahman selama 30 menit. Setelah itu dilakukan pengukuran intensitas nyeri kembali (posttest). Hasil pengumpulan data akan dicatat langsung pada lembar observasi Analisis data dilakukan secara univariat dan bivariat dengan komputerisasi. Uji statistik yang digunakan adalah T-test dependen dengan derajat kepercayaan $95 \%(\alpha=$ $5 \%$ ).

Skala nyeri yang digunakan adalah kombinasi beberapa skala nyeri, yaitu Verbal Description Scale (VDS), Comparative Pain Scale dan Wong Baker Pain Rating Scale, yang dapat disimpulkan sebagai berikut : skala $0=$ pasien tidak merasakan nyeri, skala $1=$ Pasien merasakan nyeri sangat sedikit dan tidak terfokus ke nyeri yang dirasakan., skala $2=$ pasien merasakan nyeri ringan dan mulai tidak menyenangkan, skala $3=$ nyeri lebih terasa namun bisa ditoleransi dan pasien masih bisa berkomunikasi dengan baik., skala $4=$ pasien merasakan nyeri yang kuat dan terlihat 
mendesis, skala $5=$ pasien merasakan nyeri yang dalam, terlihat menyeringai dan masih mampu menunjukkan lokasi nyeri, skala $6=$ pasien merasakan nyeri yang begitu kuat sehingga pasien tidak fokus, komunikasi mulai terganggu, namun masih dapat mengikuti perintah dengan baik, skala 7 = Pasien merasakan nyeri yang sangat kuat, sehingga pasien tidak bisa berkomunikasi dengan baik namun masih memiliki respon terhadap tindakan, Skala $8=$ pasien merasakan nyeri yang sangat kuat sehingga mempengaruhi emosi pasien, dan pasien tidak dapat mendeskripsikan nyeri yang dirasakan, Skala $9=$ Pasien merasakan nyeri yang tidak bisa ditolerir lagi dan menuntut untuk segera menghilangkan rasa sakit apapun caranya, tidak perduli efek samping/resikonya, skala $10=$ pasien merasakan sakit yang tidak terbayangkan dan tidak dapat diungkapkan serta pasien tidak mampu lagi berkomunikasi dan memukul.

\section{Hasil dan Pembahasan}

Tabel 1. Rata-rata Intensitas Nyeri Persalinan Kala I Fase Aktif Sebelum dan Sesudah Diberikan Terapi Murottal Quran Di BPM Ernita Pekanbaru Tahun 2017

\begin{tabular}{cccc}
\hline $\begin{array}{c}\text { Intensitas } \\
\text { Nyeri }\end{array}$ & $\mathrm{N}$ & Mean & $\begin{array}{c}\text { Std } \\
\text { Deviasi }\end{array}$ \\
\hline Sebelum & 20 & 6.75 & 1.41 \\
Sesudah & 20 & 4.80 & 1.24 \\
\hline
\end{tabular}

Tabel 2. Perbedaan Intensitas Nyeri Persalinan Kala I Fase Aktif Sebelum dan Sesudah Diberikan Terapi
Murottal Quran Di BPM Ernita Pekanbaru Tahun 2017

\begin{tabular}{cccccc}
\hline \multirow{2}{*}{$\begin{array}{c}\text { Perbed } \\
\text { aan } \\
\text { Intensi } \\
\text { tas } \\
\text { Nyeri }\end{array}$} & Mean & SD & \multicolumn{2}{c}{$\mathrm{CI}(95 \%)$} & $\begin{array}{c}\mathrm{P} \\
\text { valu }\end{array}$ \\
\cline { 3 - 5 } & & & Lower & $\begin{array}{c}\text { Uppe } \\
\mathrm{r}\end{array}$ & $\mathrm{e}$ \\
\hline
\end{tabular}

Hasil uji statistik menunjukkan bahwa ada perbedaan intensitas nyeri persalinan kala I fase aktif sebelum dan sesudah diberikan terapi murottal quran dengan rata-rata penurunan nyeri sebesar 1.95. Penelitian ini sejalan dengan penelitian yang dilakukan oleh Rahma Yana, dkk (2015) tentang efektivitas terapi murottal Al-Quran terhadap intensitas nyeri persalinan kala I fase aktif di RSUD Petala Bumi Pekanbaru, yang menyatakan bahwa terdapat perbedaan yang signifikan antara mean intensitas nyeri persalinan sebelum dan sesudah diberikan terapi murottal Al-Quran dengan $p$ value $(0.000)<\alpha(0.05)$.

Nyeri persalinan berasal dari kontraksi rahim yang menyebabkan dilatasi dan penipisan serviks, serta iskemia rahim akibat kontraksi arteri miometrium (Bobak, Lowdermilk \& Jensen, 2004). Setiap kontraksi umumnya berlangsung sekitar 45-90 detik, yang pada awal kala I kontraksi cenderung dirasakan pada daerah punggung bagian bawah. Semakin majunya persalinan, maka intensitas kontraksi akan semakin meningkat sehingga nyeri yang dirasakan akan semakin kuat terutama pada daerah abdomen dan punggung (Reeder, 2011).

Setiap individu memiliki ambang batas dan toleransi terhadap nyeri yang berbeda-beda. Saat ibu bersalin memfokuskan perhatiannya 
terhadap nyeri yang dirasakan, hal tersebut akan mempengaruhi persepsi nyeri sehingga nyeri yang dirasakan akan meningkat. Banyak faktor yang mempengaruhi nyeri persalinan, yaitu usia dalam menghadapi persalinan, pengalaman nyeri persalinan sebelumnya, dukungan dan perhatian dari pendamping persalinan, kecemasan terhadap persalinan yang akan dihadapi, kebudayaan dan teknik koping. Menurut Potter dan Perry (2012), selama kontraksi dan relaksasi persalinan, ibu bersalin membutuhkan sesuatu yang dapat meringankan nyeri yang dirasakan. (Manurung, 2011; Potter PA dan Perry AG, 2012).

Banyak metode pengurangan nyeri persalinan yang dapat diterapkan salah satunya yaitu metode distraksi yang mempunyai pengaruh paling baik untuk mengatasi nyeri. Distraksi artinya mengalihkan perhatian pasien ke hal lain sehingga dapat menurunkan kewaspadaan terhadap nyeri dan bahkan meningkatkan ambang batas/toleransi terhadap nyeri. Beberapa metode distraksi yang dapat diterapkan adalah menyanyi, melihat gambar, berdoa, dan mendengarkan musik. Musik adalah salah satu distraksi yang paling efektif untuk menurunkan nyeri fisiologis, stress dan kecemasan sehingga dapat mengalihkan perhatian seseorang dari nyeri yang dirasakannya. Terapi berupa suara terbukti memberikan efek terhadap tanda-tanda vital, yaitu menurunkan frekuensi denyut jantung, mengurangi kecemasan dan depresi, menghilangkan nyeri dan menurunkan tekanan darah (Potter PA dan Perry AG, 2012)

$\begin{array}{cr}\text { Alfred Tomatis, } & \text { seorang } \\ \text { dokter } \quad \text { Perancis, } & \text { membuat }\end{array}$

eksperimen selama lima puluh tahun mengenai indera manusia dan menyatakan bahwa indera pendengaran adalah indera yang paling penting. Dokter ini menemukan bahwa telinga mengontrol seluruh tubuh, mengatur operasi-operasi vitalnya dan keseimbangan serta koordinasi gerakan-gerakannya. Saraf pendengaran terhubung dengan seluruh otot tubuh dan ini adalah alasan mengapa keseimbangan dan fleksibilitas tubuh serta indera penglihatan terpengaruh oleh suara. Telinga dalam terhubung dengan seluruh bagian tubuh seperti jantung, paru-paru, hati, perut dan usus. Hal ini menjelaskan mengapa frekuensi suara dapat mempengaruhi seluruh tubuh (Huda SE, 2015).

Seni membaca Al-quran merupakan alunan intonasi atau membaca $A l$-quran yang disuarakan dalam keindahan raga nada, variasi serta improvisasi selaras dengan pesanpesan yang diungkapkan oleh ayat-ayat yang dibaca. Dalam seni membaca $A l$ quran terdapat 7 macam lagu yang dapat disuarakan, yaitu bayyati, shoba, nahawand, hijaz, rost, sika, dan jiharka. (Ismail, 2014). Membaca Alquran dengan murottal merupakan cara yang sering kita temui dan hampir dipelajari semua muslim di dunia. Murottal adalah membaca Al-quran yang menfokuskan pada dua hal, yaitu kebenaran bacaan dan lagu Al-quran. Konsentrasi bacaan difokuskan pada penerapan tajwid sekaligus lagu, maka porsi lagu quran tidak dibawakan sepenuhnya. Hanya pada nada asli dengan tingkat suara sedang sehingga dapat memberikan ketenangan (Anonim, 2015). 
Murottal Quran merupakan salah satu pilihan suara yang dapat didengarkan ibu bersalin untuk mengurangi nyeri persalinan. Mendengarkan murottal quran akan memberikan stimulus kepada indra pendengar sehingga ibu akan terfokus kepada suara yang didengarkan dan membuat ibu mampu merelaksasikan diri. Hal ini memberikan efek hypnosis yang akan membantu memudahkan ibu dalam menghadapi persalinan. Suara al-quran dapat mengurangi kecemasan mengahadapi persalinan, membantu ibu lebih rileks dan meningkatkan semangat dalam mengahadapi persalinan.

Dr. Al Qadhi, seorang dokter ahli jiwa pernah melakukan penelitian panjang di Klinik Besar Florida Amerika Serikat. Penelitian ini berhasil membuktikan bahwa hanya dengan mendengarkan bacaan ayat-ayat $A l$ quran, seorang Muslim, baik mereka yang berbahasa Arab maupun bukan, dapat merasakan perubahan fisiologis yang sangat besar. Pengaruh umum yang dirasakan objek penelitiannya adalah penurunan depresi dan kesedihan, memperoleh ketenangan jiwa serta menangkal berbagai macam penyakit. Penemuan dokter ini ditunjang dengan bantuan peralatan elektronik untuk mendeteksi tekanan darah, detak jantung, ketahanan otot, dan ketahanan kulit terhadap aliran listrik. Hasil uji cobanya menunjukkan bahwa bacaan Al-quran berpengaruh besar hingga $97 \%$ dalam melahirkan ketenangan jiwa dan penyembuhan penyakit (Azzam, Y, 2013).

Pada penelitian ini, peneliti memberikan terapi murottal quran kepada ibu bersalin kala I fase aktif (pembukaan serviks 4-8 $\mathrm{cm}$ ) selama 30 menit. Murottal quran yang diperdengarkan kepada ibu adalah surat Ar-rahmaan dengan menggunakan headset, kemudian ibu diminta untuk memejamkan mata saat mendengarkannya agar ibu hanya fokus pada suara yang diperdengarkan. Metode ini dilakukan agar tubuh ibu mengalami relaksasi.

Pada saat mengalami relaksasi, tubuh akan secara alami mengeluarkan endorphin yang mampu menghambat pelepasan substansi $\mathrm{P}$ (substancia gelatinosa) pada kornu dorsalis di spinal cord sehingga tidak ada persepsi nyeri di korteks cerebri. Endorphin dapat berupa neurotransmitter atau neuromedulator yang menghambat transmisi/pengiriman nyeri. Hal ini akan membuat ibu bersalin menjadi lebih tenang. Oleh karena itu pelaksanaan murottal quran harus dilakukan dalam keadaan lingkungan yang aman dan tenang (Manurung, 2011).

Banyak efek menakjubkan yang dapat terjadi apabila seorang Muslim mendengarkan bacaan $\mathrm{Al}$ quran, yaitu meningkatkan kemampuan konsentrasi, menciptakan kedamaian, menyembuhkan ketegangan saraf, menyembuhkan kegelisahan, serta mengurangi rasa takut dan ragu-ragu (Masrifah, Z, 2014). Penelitian yang dilakukan oleh Roghayeh Bayrami dan Hossein Ebrahimipour (2014) tentang efek suara Al-quran terhadap nyeri persalinan dan faktor neonatal pada ibu primipara menyatakan bahwa, suara Al-quran sangat direkomendasikan sebagai metode pengurangan nyeri non-farmakologis yang diterapkan selama persalinan kala I fase aktif. Selain mempunyai dampak positif 
terhadap penurunan nyeri persalinan, suara Al-quran juga terbukti mempercepat proses persalinan, menstabilkan tanda-tanda vital ibu dan apgar skor bayi.

Penelitian lain yang dilakukan oleh Sedigheh Forouhari, et al (2011) yang berjudul "Evaluation of The Auditory Effects of The Sounds of Quarn E Karim on Labor Pain" di Iran menyatakan bahwa suara Al-quran adalah lagu yang paling indah dengan kata-kata yang menenangkan sehingga memberikan efek sebagai penyembuh. Penelitian ini juga menyatakan bahwa dengan mendengarkan suara al-quran akan memberikan ketenangan pada mental ibu bersalin sehingga dapat mengontrol nyeri yang dirasakan.

Menurut peneliti, nyeri merupakan keadaan fisiologis selama bersalin yang sangat dipengaruhi oleh keadaan fisik, mental, sosial serta spiritual seseorang. Seorang ibu bersalin berada dalam keadaan yang sangat membutuhkan perhatian serta dukungan untuk membantu meringankan nyeri yang dirasakan dalam menghadapi persalinan. Memberikan terapi murottal quran selama kala I persalinan akan memberikan kenyamanan dan menurunkan kecemasan ibu dalam menghadapi persalinan, karena telah terbukti dalam berbagai penelitian bahwa efek suara al-quran tidak hanya membantu meringankan nyeri persalinan, namun juga memberikan efek yang positif terhadap tanda-tanda vital ibu serta janin sehingga persalinan dapat berjalan dengan lancar Pada penelitian ini peneliti tidak meneliti kecemasan responden, membedakan Ibu bersalin primipara dan multipara, melihat adanya dukungan keluarga serta usia ibu sehingga pengurangan rasa nyeri pada ibu bersalin pada penelitian ini memang hanya dipengaruhi oleh faktor pemberian terapi murrotal Qur'an atau dapat dipengaruhi oleh faktor lain yang tidak diteliti sebagai variabel counfonding Hal ini merupakan keterbatasan dalam penelitian ini.

\section{Simpulan}

Rata-rata (mean) intensitas nyeri persalinan sebelum diberikan terapi murottal qur'an adalah 6,75 dan setelah diberikan terapi murottal qur'an adalah 4,80. Ada perbedaan intensitas nyeri persalinan kala I fase aktif sebelum dan sesudah diberikan terapi murottal Qur'an di BPM Ernita ( $p$ value $=0,000)$

Disarankan kepada BPM Ernita untuk melakukan sosialisasi tentang terapi murottal qur'an sebagai salah satu metode pengurangan nyeri persalinan non-farmakologis, sehingga kedepannya dapat dipertimbangkan menjadi sebuah prosedur asuhan persalinan terutama dalam membantu mengurangi nyeri. Diharapkan penelitian ini dapat menjadi dasar bagi peneliti lain untuk melakukan penelitian yang sama dengan menambahkan variabel lain dan dengan sampel yang lebih banyak, desain penelitian yang berbeda dan ruang lingkup yang lebih luas dan waktu yang lebih lama.

\section{Daftar Pustaka}


Abdillah, A. 2007. Bila Sakit Menyapa. Jawa Timur: Pustaka Al-Furqon.

Alice Rich, RN. 2012. Comparative Pain Scale or 0-10 Pain Scale. Lucile Packard Children's Hospital Heart Center/CVICU. http://pudendal.info/info/docum ents/ComparativePainScale.htm . Diakses tanggal 22 Februari 2017.

Anonim. 2014. www.tahsinwest.com. (diakses tanggal 16 Februari 2017).

Anonim. 2015. Apa Itu Mujawwad dan Murottal.

https://kafesite.wordpress.com/ 2015/09/21/apa-itumujaawwad-dan-murottal/ (diakses tanggal 24 Juli 2017).

Asrinah, et al. 2010. Asuhan Kebidanan Masa Persalinan. Yogyakarta: Graha Ilmu.

Azzam, Y. 2013. Inilah Salah Satu Mukjizat Al-Quran di Kehidupan Modern Saat Ini. https://www.kaskus.co.id/threa d/527bb7fda1cb17dc4b000004/ manfaat-ilmiah-membaca-danmendengar-al-quran/ (diakses tanggal 23 Juli 2017).

Bayrami, R., dan Ebrahimipour, $\mathrm{H}$. 2014. Effect of the Quran Sound on Labor Pain and Other Maternal and Neonatal Factors in Nulliparous Women. Iran: Journal of Research Volume 4 No.4.
Bobak, Lowdermik, dan Jensen. 2004. Buku Ajar Keperawatan Maternitas. Jakarta: EGC.

Cunningham, FG., et al. 2012. Obstetri Wiiliams. Jakarta: EGC.

Forouhari, S., et al. 2011. Evaluation of the Auditory Effects of the Sound of Quarn e Karim on Labor Pain. Iran: Quran Medicine 2011;1(2):14-18.

Henderson, C., dan Jones, K. 2005. Buku Ajar Konsep Kebidanan. Jakarta: EGC.

Hidayat, AA dan Hidayat, M. 2008. Keterampilan Dasar Praktik Klinik untuk Kebidanan. Jakarta: Salemba Medika.

Huda, SE. 2015. Mendengar Alquran Menenangkan Jiwa? Ini Penjelasannya.

https://www.dream.co.id/news/ mendengar-alquranmenenangkan-jiwa-inipenjelasannya-150304a.html (diakses tanggal 23 Juli 2017)

Ismail. 2014. 7 Macam Lagu Dalam Seni Membaca Al-Qur'an. https://coretanhampa.blogspot.com/2014/04/7 -macam-lagu-dalam-senimembaca-al-quran_28.html (diakses tanggal 23 Juli 2017).

JNPK-KR. 2008. Buku Acuan Pelatihan Klinik Asuhan Persalinan Normal. Jakarta: Departemen Kesehatan Republik Indonesia. 
Manuaba, IBG., et al. 2007. Pengantar Kuliah Obstetri. Jakarta: EGC.

Manurung, S. 2011. Buku ajar Keperawatan Maternitas Asuhan Keperawatan Intranatal. Jakarta: TIM.

Masrifah, Z. 2014. Kekuatan Penyembuhan dengan AlQur'an Berdasarkan Penelitian Ilmiah.

http://azzahramasrifah.blogspot .co.id/2014/11/manfaatmendengar-suara-al-qurandapat.html (diakses tanggal 23 Juli 2017)

Medforth, J., et al 2011. Kebidanan Oxford: dari Bidan untuk Bidan. Jakarta: EGC.

Potter. PA., dan Perry. AG. 2005. Buku Ajar Fundamental Keperawatan: Konsep, proses, dan praktik. Jakarta: EGC.

Ranta. P., et al. 1995. Maternal Expectastions and Experiences of Labour Pain-Options of 1091 Finnish Parturients. Findland: Acta Anastesional Scan 1995: 39: 60-66.

Reeder, SJ., Martin, LL., dan Griffin, DK. 2011. Keperawatan Maternitas: Kesehatan Wanita, Bayi, \& Keluarga. Jakarta: EGC.

Rohani, Saswita. R., dan Marisah. 2011. Asuhan Kebidanan Pada Masa Persalinan. Jakarta: Salemba Medika.
Prawirohardjo, S. 2010. Ilmu Kebidanan. Jakarta: PT Bina Pustaka Sarwono Prawirohardjo.

Simkin, P., dan Bolding, A. 2004. Update on Nonpharmacologic Approaches to Relieve Labor Pain and Prevent Suffering. Amerika: Journal of Midwifery and Women's Health: Volume 49 No. 6.

Simkin, P., Whalley, J., dan Keppler, A. 2007. Panduan Lengkap Kehamilan, Melahirkan dan Bayi. Jakarta: ARCAN.

Sugiyono, Prof. DR. 2011. Statistika Untuk Penelitian. Bandung: Alfabeta.

Sulistyawati, A., dan Nugraheny. 2010. Asuhan Kebidanan pada Ibu Bersalin. Jakarta: Salemba Medika.

Yana, R., Utami, S., dan Safri. 2015. Efektivitas Terapi Murottal AlQur'an Terhadap Intensitas Nyeri Persalinan Kala I Fase Aktif. Pekanbaru: JOM Vol. 2 No. 2.

Yudiyanta, Khoirunnisa, N dan Novitasari, RN. 2015. Assessment Nyeri. Yogyakarta: Departemen Neurologi, Fakultas Kedokteran Universitas Gadjah Mada, Indonesia CDK-226/Vol. 42 No. 3. 